\title{
TOMASZ WIELEBSKI \\ MATEUSZ J. TUTAK \\ Diagnoza i prognoza jako narzędzie dialogu teologii pastoralnej z socjologią na przykładzie świętowania niedzieli i starzenia się społeczeństwa w Polsce
}

Drugi Sobór Watykański, wskazując konieczność właściwego harmonizowania kultury ludzkiej i obywatelskiej z nauką chrześcijańską, podkreślił konieczność uznawania i stosowania w duszpasterstwie nie tylko zasad teologii, ale także nauk świeckich, zwłaszcza psychologii i socjologii (zob. KDK 62). Z kolei Jan Paweł II w adhortacji apostolskiej Familiaris consortio stwierdził, że Kościół docenia badania socjologiczne $i$ statystyczne, o ile okazuja się pożyteczne dla uchwycenia kontekstu historycznego, w którym ma on rozwijać działalność pasterska i dla lepszego poznania prawdy (FC 5). Aby dobrze zrealizować to nauczanie Magisterium, potrzeba współpracy całego Ludu Bożego, który z pomocą Ducha Świętego będzie odczytywał, rozważał i interpretował w świetle słowa Bożego znaki czasu (zob. KDK 4; 44). Podjęcie naukowego dialogu między osobami duchownymi i świeckimi przedstawicielami różnych nauk będzie nie tylko służyło lepszemu odczytaniu uwarunkowań pracy duszpasterskiej Kościoła, ale również ukaże w sposób czytelny Jego istotę. Kościół bowiem jest wspólnotą, za urzeczywistnianie której odpowiadają zarówno duchowni, jak i świeccy ${ }^{1}$.

Tomasz W I E L E B S K I, ks. dr teologii pastoralnej; adiunkt w Katedrze Organizacji Duszpasterstwa Wydziału Teologicznego UKSW oraz wykładowca WSD Diecezji Warszawsko-Praskiej, Warszawa, e-mail: t.wielebski@wp.pl

Mateusz J. T U T A K, mgr socjologii i teologii, doktorant w Sekcji Teologii Pastoralnej WT UKSW w Warszawie, wychowawca w bursie salezjańskiej w Warszawie oraz nadzwyczajny szafarz Komunii świętej w archidiecezji łódzkiej, e-mail: matitux@gmail.com 
Celem artykułu jest teoretyczne, a także praktyczne ukazanie sposobu, w jaki teologia może nawiązać dialog z socjologią w służbie realizacji zbawczego działania Kościoła. Narzędziem tego dialogu ma być diagnoza dotycząca przeżywania Dnia Pańskiego przez polskich katolików oraz prognoza dotycząca przemian demograficznych $\mathrm{w}$ naszym kraju. Prowadzone rozważania będą umiejscowienie w szerszym kontekście relacji między teologią pastoralną i socjologią. Owocem tych relacji ma być zaproponowanie pewnych działań duszpasterskich służących lepszemu wypełnianiu przez Kościół Jego zbawczej misji.

\section{Relacja między teologią pastoralną a socjologią}

$\mathrm{Na}$ użytek niniejszego artykułu wyjaśnienie, czym jest teologia pastoralna, zostanie ograniczone do pierwszej części opisu zawartego w punkcie 57 posynodalnej adhortacji Pastores dabo vobis. Jest tam ona określona jako naukowa refleksja o codziennym wzrastaniu Kościoła, w mocy Ducha Świętego, w kontekście historii (PDV 57). Analiza terminów zawartych w tej definicji wskazuje na głębokie osadzenie teologii, którą potocznie nazywamy nauką o Bogu, w kontekście świata ujmowanego w określeniach codzienny i historia oraz nauk empirycznych, które ten świat opisują ${ }^{2}$.

Aby teologia pastoralna mogła dobrze realizować swoje zadanie podejmowania naukowej refleksji Kościoła nad samym sobą, potrzebuje ona również wyników badań empirycznych. Zinterpretowane teologicznie wyniki tych badań są sposobem odczytywania znaków czasu, wprowadzając myśl teologiczną do społeczeństwa osadzonego w określonym kontekście kulturowym. Teologia pastoralna w sposób naukowy podejmuje krytyczną analizę nie tylko służącą sprawdzeniu zasadności i skuteczności prowadzonych działań duszpasterskich, ale także procesów zachodzących we współczesnych społeczeństwach. Nie pozostaje ona jedynie na etapie opisywania kairos, ale za pomocą teologicznosocjologicznej analizy konkretnej, teraźniejszej sytuacji Kościoła zmierza do wypracowania aktualnych modeli teologicznych oraz odpowiadających im imperatywów i programów działania. Według nich Kościół aktualizuje własną istotę, wypełniając misję pośrednictwa zbawczego ${ }^{3}$. Przyzwolenie na tę metodę pracy

\footnotetext{
${ }^{1}$ Praktycznym wyrazem tej odpowiedzialności, a zarazem przykładem dialogu między teologią a innymi naukami, jest niniejszy artykuł napisany wspólnie przez teologa-pastoralistę i socjologa.

${ }^{2}$ R. K a m ińs ki: Wprowadzenie do teologii pastoralnej. W: Teologia pastoralna. T. 1. Red. R. K a mi ń s ki. Lublin 2000 s. 19-21.

${ }^{3} \mathrm{~W}$. P i w o w a r s ki: Perspektywa teologiczna a perspektywa socjologiczna $w$ duszpasterstwie. „Chrześcijanin w Świecie”. R. 1973 nr 26 s. 30.
} 
dał II Sobór Watykański w przywoływanym już fragmencie Konstytucji duszpasterskiej o Kościele w świecie współczesnym Gaudium et spes (KDK 62). Takie ukierunkowanie teologii pastoralnej i pracy duszpasterskiej na wymiar antropologiczny dostrzec można także w cytowanej wyżej posynodalnej adhortacji $\mathrm{Pa}$ stores dabo vobis, gdzie wprost wskazano na to, że w głębszym zrozumieniu człowieka oraz zjawisk i kierunków rozwoju społecznego bardzo pomocne mogą być nauki o człowieku (zob. PDV 52).

Złożoność współczesnego świata i sytuacji różnych kategorii wiernych, środowisk oraz instytucji religijnych nie pozwala na to, aby wspomniane sprawy pozostawić tylko duszpasterskiej intuicji. Odpowiedzialność za powierzoną misję nie pozwala również na to, aby opierać swoją pracę na własnym oglądzie świata. Akademickie ośrodki teologiczne winny dysponować narzędziami, które pomogą poznać, zrozumieć i odnaleźć się w rzeczywistości zmieniającego się społeczeństwa. Aby osiagnąć ten cel, konieczna jest ścisła współpraca pastoralistów z przedstawicielami nauk społecznych. Szczególnie istotną rolę w dyskursie naukowym z teologią ma socjologia, która opisuje i diagnozuje rzeczywistość społeczną. Aby zachować autonomiczność obydwóch dyscyplin, w prowadzonym dialogu powinny brać udział osoby będące przynajmniej po podstawowym kursie $\mathrm{z}$ tych dziedzin, zwłaszcza $\mathrm{w}$ zakresie teologii pastoralnej i socjologii religii. W ten sposób znacznie łatwiej będzie socjologowi zrozumieć na przykład praktyczne kompetencje władzy hierarchicznej w duszpasterstwie, a teologowi interpretację rzeczywistość przez weryfikację hipotez.

Uświadomienie różnic między tymi naukami pozwoli teologom i socjologom współpracować z pełnym wykorzystaniem dostępnych metod badawczych, bez uszczerbku dla żadnej z tych dziedzin. O ile teologia pastoralna ocenia zastany porządek, o tyle socjologia ogranicza się do jej opisu, porównania czy klasyfikacji. Jest to szczególnie ważne w dalszym procesie metodologicznym, w którym obydwie nauki interpretują zastane fakty. Teologia dokonuje tego w świetle Objawienia, socjologia zaś w świetle hipotez i empirii, nierzadko prezentowanych metodą ilościową, czyli przez liczby. Stosowana metoda to jedna z głównych różnic między obu dziedzinami, a jednocześnie płaszczyzna, na której najlepiej widać możliwości współpracy między obiema naukami.

Socjologia religii, będąca subdyscypliną socjologii ogólnej, zajmuje się strukturami, funkcjami i procesami w społeczności Kościoła, poddając je badaniom ilościowym bądź jakościowym. Teologia pastoralna natomiast, jako metodą przy konstruowaniu modeli teologicznych, posługuje się sylogizmem praktycznym. Na jego pierwszym etapie tworzone są kryteria, według których jest rozpatrywana podejmowana problematyka. Sięgniecie do owoców pracy teologii dogmatycznej, biblijnej lub moralnej służy tworzeniu podstaw teologicznych 
zagadnień będących przedmiotem poszukiwań pastoralnych. Następnie badacz odwołuje się do zastanej rzeczywistości, korzystając między innymi właśnie z analiz socjologicznych. Dokonujące się przemiany, ich impet i szybkość wymagają tego, aby pastoralista miał ciągle kontakt z rzeczywistością społeczna. Czyni to dzięki współpracy z socjologiem, który pomaga jemu stawiać diagnozę i prognozę, wykrywa prawidłowości życia religijnego, pokazuje nowe tendencje, czy też służy pomocą w rozwiązywaniu konkretnych zadań. Socjolog wskazuje stan moralno-religijny i czynniki społeczne, historyczne oraz kulturowe wpływające na życie religijne. Innymi słowy, socjolog ukazuje pastoraliście prawidłowości, tendencje i teorie panujące w świecie społecznym. Teolog wykorzystuje zdobytą wiedzę do tworzenia narzędzi służących stawianiu diagnozy pastoralnej i określaniu kierunków dalszej działalności eklezjalnej. Etap ten nazywany jest prakseologicznym, gdyż to na nim budowane są modele pastoralne, które mają być wykorzystywane w pracy duszpasterskiej. Zarówno na etapie kariologicznym, jak i prakseologicznym, niezastąpiona okazuje się więc współpraca teologii pastoralnej z socjologią, zwłaszcza socjologią religii ${ }^{4}$.

\section{Diagnoza dotycząca świętowania niedzieli i prognoza starzenia się społeczeństwa w Polsce}

Po wyjaśnieniu dialogicznych relacji między teologią pastoralną a socjologią, postaramy się teraz przedstawić, w oparciu o wyniki badań socjologicznych przeprowadzonych przez różne instytuty badawcze, diagnozę dotyczącą świętowania niedzieli oraz prognozę mówiącą o starzeniu się społeczeństwa w Polsce. Stawiana diagnoza oraz ukazywana prognoza zostaną pokazane w perspektywie wskazań płynących z nauczania Magisterium Kościoła. Pozwoli to w konsekwencji na zaproponowanie pewnych kierunków działań dla Kościoła w Polsce.

Niedziela, nazywana w Piśmie Świętym pierwszym dniem tygodnia (Mt 28,1) i dniem Pańskim (Ap 1,10), jest najstarszym dniem świątecznym chrześcijan obchodzonym na pamiątkę zmartwychwstania Chrystusa. II Sobór Watykański w Konstytucji o liturgii świętej Sacrosantum concilium uczy, że niedziela jest świętowaniem zmartwychwstania Chrystusa oraz czasem radości i odpoczynku (zob. KL 106). Głównym elementem chrześcijańskiego świętowania Dnia Pańskiego jest udział w Eucharystii, będącej sercem niedzieli i w szczególny sposób budującej wspólnotę z Chrystusem i innymi ludźmi (zob. DD 35). Katechizm Kościoła katolickiego z 1992 r. mocno akcentuje obowiązek świętowania niedzieli jako przepisu moralnego w sposób naturalny wpisanego w serce człowieka (zob. KKK 2176), zwracając uwagę na to, że wierni w tym dniu nie

\footnotetext{
${ }^{4}$ R. K a m i ń s k i: Wprowadzenie do teologii pastoralnej, dz. cyt., s. 27-29.
} 
tylko powinni powstrzymać się od różnych prac, ale świętować go, spełniając uczynki miłosierdzia, poświęcając czas rodzinie i bliskim oraz dbając o swój wszechstronny rozwój. Mają oni też domagać się uznania niedziel i świqut kościelnych za ustawowe dni świqteczne (zob. KKK 2184-2188).

Jan Paweł II w liście apostolskim Dies Domini z 1998 r. podkreśla, że w wielu krajach świętowanie niedzieli przeżywa kryzys, wyrażający się zatraceniem pierwotnego sensu tego dnia i spadkiem liczby osób uczestniczących w niedzielnej Eucharystii (DD 4-5). Czy do tych krajów można również zaliczyć Polskę? Próbując postawić właściwą diagnozę omawianego zjawiska, przyjrzyjmy się wybranym wynikom badań.

Jak na przestrzeni lat kształtuje się w Polsce praktyka niedzielnego udziału w Eucharystii? Aby oddać faktyczny stan rzeczy, należy odwołać się zarówno do wyników badań religijności Polaków prowadzonych przez różne instytuty badawcze, jak również do wskaźników osób uczestniczących we mszy św. we wszystkich polskich parafiach w wybraną niedzielę roku (dominicantes) i przyjmujących podczas niej Komunię świętą (communicnates) $)^{5}$.

Badania religijności Polaków prowadzone przez CBOS na przestrzeni 20 lat (1989-2008) wskazują na to, że trwałą cechą Polaków jest, oprócz powszechnie deklarowanej wiary w Boga (ok. 95,0\% uważa się za katolików), trwałe i stosunkowo silne przywiązanie do praktyk religijnych (msze św., nabożeństwa, spotkania religijne). Ponad połowa badanych (odsetek ten waha się od 55,0\% do $60,0 \%)$ twierdzi, że bierze udział w praktykach religijnych przynajmniej raz w

\footnotetext{
${ }^{5}$ Instytut Statystyki Kościoła Katolickiego SAC prowadzi od 1979 r. w wybraną niedzielę roku we wszystkich polskich parafiach liczenie wiernych obecnych na mszy św., jak też przystępujących do Komunii św. Wskaźnik dominicantes oblicza się dla każdej parafii jako odsetek wiernych uczęszczających na niedzielną mszę świętą w odniesieniu do ogólnej liczby zobowiązanych. Dla wszystkich parafii przyjęto to samo założenie, że zobowiązani do uczęszczania na niedzielną mszę świętą stanowią $82,0 \%$ wiernych $(18,0 \%$ to dzieci do lat siedmiu, chorzy, starsi, matki opiekujące się małymi dziećmi itp.). Wskaźnik dominicantes nie pokrywa się $\mathrm{z}$ odsetkiem praktykujaccych $\mathrm{w}$ ogóle, gdyż w zasadzie nie obejmuje on tych, którzy praktykują w wielkie święta lub tylko z okazji chrztu dziecka, ślubu kościelnego czy pogrzebu bliskiej osoby. Z kolei termin communicantes jest używany na określenie proporcji między liczbą osób przystępujących do Komunii świętej w przeciętną niedzielę roku a liczbą osób obecnych w kościele w tę samą niedzielę. Wspomniane wskaźniki mają charakter obiektywny, gdyż są ustalane na podstawie przeliczenia wiernych obecnych $\mathrm{w}$ kościele podczas spełniania obydwu praktyk [W. Z d a n i e wi c z, L. A d a m c z u k, Wstęp. W: Kościót i religijność Polaków 1945-1999. Red. W. Z d a n i e w i c z, T. Z e m b r z u s k i. Warszawa 2000 s. 45-452].
} 
tygodniu, około jedna piąta dwa razy w miesiącu, podobny odsetek kilka razy w roku, mniej więcej ośmiu na stu przyznaje się do niepraktykowania ${ }^{6}$.

Na wysoki poziom uczestnictwa we mszy św. niedzielnej wskazują także trzy ogólnopolskie sondaże realizowane przez Instytut Statystyki Kościoła Katolickiego SAC. W 1991 r. 37,8\% dorosłych Polaków deklarowało systematyczny udział we mszy św. niedzielnej, prawie w każdą niedzielę było na mszy św. niedzielnej $27,5 \%$ badanych, jeden lub dwa razy w miesiącu 17,1\%, w wielkie święta $11,5 \%$, rzadziej niż raz w roku $4,8 \%$ respondentów, nie udzieliło odpowiedzi $3,1 \%$ badanych $^{7}$. Z kolei ogólnopolski sondaż ISKK SAC przeprowadzony $\mathrm{w}$ 1998 r. wykazał, że we mszy św. w każdą niedzielę lub sobotę wieczorem i święta uczestniczyło $42,0 \%$, prawie w każdą niedzielę $22,9 \%$, jeden lub dwa razy w miesiącu $11,4 \%$, tylko w wielkie święta $10,1 \%$, tylko z okazji ślubu lub pogrzebu itp. $4,5 \%$, w ogóle nie uczestniczyło we mszy św. $4,8 \%$, nie udzieliło odpowiedzi $1,2 \%^{8}$. Badania przeprowadzone przez ten sam ośrodek badawczy w $2002 \mathrm{r}$. wykazały, że w każdą niedzielę albo w sobotę uczęszczało na mszę św. 44,6\% respondentów, prawie w każdą niedzielę $20,6 \%$, jeden lub dwa razy w miesiącu $14,3 \%$, tylko w wielkie święta $11,1 \%$, tylko z okazji ślubu lub pogrzebu itp. $3,6 \%$, w ogóle nie uczestniczyło we mszy św. 5,0\%, nie udzieliło odpowiedzi $0,7 \%^{9}$. Zestawiając ze sobą wyniki uzyskanych badań, można stwierdzić, że wskaźnik osób uczęszczających do kościoła na mszę św. w każdą lub prawie każdą niedzielę utrzymywał się na przestrzeni 10 lat zasadniczo na tym samym poziomie $(65,3 \%, 68,0 \%, 65,2 \%)$.

Pamiętając o tym, że istnieje różnica między deklarowanymi zachowaniami religijnymi a stanem faktycznym, należy skonfrontować dane uzyskiwane drogą badań ankietowych z bezpośrednimi badaniami dominicantes i communicantes. Co prawda $w$ tego typu badaniach nie można zachować pełnego nadzoru nad przebiegiem liczenia osób oraz wyegzekwować danych z niektórych parafii, ale materiał empiryczny uzyskany taką drogą ma wiele cennych właściwości. Są one

${ }^{6}$ R. B o g u s z e w s k i: Polak - na zawsze katolik? Polska religijność w latach 1998-2008 na podstawie badań CBOS. „Więź”. R. 51: $2008 \mathrm{nr} 9$ s. 7-8.

${ }^{7}$ J. M a ri á s k i: Obowiazkowe praktyki religijne. W: Religijność Polaków 1991. Red. L. A d a m c z u k, W. Z d a n i e w i c z. Warszawa 1993 s. 72-73.

${ }^{8} \mathrm{~J}$. M ariań ski: Niedzielne i wielkanocne praktyki religijne. W: Religijność Polaków 1991-1998. Red. W. Z d a n i e w i c z. Warszawa 2001 s. 86-87.

${ }^{9}$ S. H. Z a r ę b a: Rytualistyczne zaangażowanie Polaków - regres czy stabilizacja? W: Kościót katolicki na poczqtku trzeciego tysiqclecia w opinii Polaków. Red. W. Z d a n i e w i c z, S. H. $\mathrm{Z}$ a r ę b a. Warszawa 2004 s. 66-67. 
niezależne od subiektywnych deklaracji respondentów, powtarzając je cyklicznie, można mówić o pewnych zależnościach ${ }^{10}$.

Jak kształtował się wskaźnik dominicantes w Polsce na przestrzeni 30. lat?

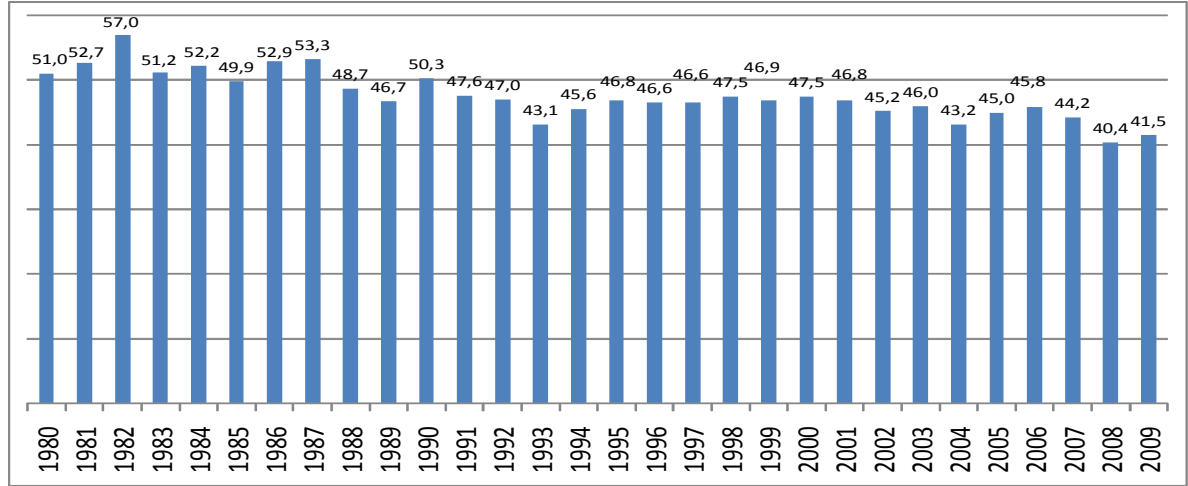

Wykres 1. Wskaźnik dominicantes w Polsce w latach 1980-2010. Dane w \%. Źródto: ISKK SAC

W oparciu o dane zbierane od 1979 r. przez ISKK SAC możemy wyróżnić trzy okresy przemian w uczestnictwie we mszy św. niedzielnej. Do 1990 r. liczba uczestniczących w niedzielnych mszach św. wynosiła 50,0\% i więcej (198753,3\%). Po 1990 roku liczba osób uczestniczących w niedzielnej Eucharystii utrzymywała się na poziomie od $43,1 \%$ do $47,6 \%$. Nowy okres rozpoczął się w 2008 r., kiedy średnia dominicantes spadła do 40,4\%. Chociaż w 2009 r. wyniosła ona $41,5 \%$, to są podstawy do mówienia o pewnym jej spadku w kolejnych latach $^{11}$. Nie jest to co prawda tak dramatyczny spadek uczestnictwa we mszy św. jaki obserwujemy w krajach Europy Zachodniej, ale jednak uzyskane dane powinny nas pobudzić do pewnej czujności, wyrażającej się w podejmowaniu odpowiednich działań duszpasterskich ${ }^{12}$.

${ }^{10}$ G. Gu d a s ze w s ki: Statystyka praktyk niedzielnych $w$ diecezjach objętych badaniami postaw religijnych, w: Religia. Kościót. Społeczeństwo. Wyniki badań socjologicznych w 12 diecezjach 1996-2006. Red. W. Z d a n i e w i c z, S. H. Z a r ę b a. Warszawa 2006 s. 142-143.

${ }^{11}$ G. G u d a s z e w s k i: Statystyka dominicantes $i$ communicantes jako metoda obserwacji $i$ analizy aktywności. W: Socjologia życia religijnego $w$ Polsce. Red. S. H. Z a r ę b a. Warszawa 2009 s. 160-162; R. M o l e n d a: Statystycznie religijni. „Idziemy”. R. 2010 nr 22 s. 15-16; Dominicantes 2009 - 30 lat badań praktyk religijności w Polsce [www. iskk./pl/index.php?view= article\&catid=38\%3Akosciol-wpolsce@id (data pobrania 29.09.2010)].

${ }^{12}$ Przykładowo, badania na temat religijności Francuzów prowadzone przez Francuski Instytut Opinii Publicznej na zlecenie katolickiego dziennika „La Croix” prowadzone w 2009 r. wykaza- 
Na uwagę zasługuje bardzo duża rozpiętość dominicantes w poszczególnych diecezjach. Najwięcej osób uczęszczających na niedzielną Eucharystię zamieszkuje południe Polski. W 2009 r. największy wskaźnik dominicantes zaobserwowano w diecezji tarnowskiej (70,9\%), rzeszowskiej $(65,3 \%)$, archidiecezji przemyskiej $(60,6 \%)$ i krakowskiej $(51,8 \%)$. Z kolei najniższy wskaźnik dominicantes obserwuje się w archidiecezji szczecińsko-kamieńskiej (27,5\%), diecezji koszalińsko-kołobrzeskiej (28,3\%), sosnowieckiej i łódzkiej (28,7\%). Dla archidiecezji warszawskiej wskaźnik ten wyniósł $31,8 \%$, a dla diecezji warszawskopraskiej 33,9\%. ${ }^{13}$. Tak zróżnicowany wskaźnik dominicantes ma wiele uwarunkowań: historycznych, kulturowych, duszpasterskich. Również one powinny być brane pod uwagę nie tylko przy wyjaśnianiu przyczyn istniejącego stanu rzeczy, ale także przy planowaniu działań duszpasterskich.

A jak wygląda w Polsce wskaźnik communicantes w ciagu 30. lat?

W odróżnieniu od wskaźnika dominicantes, zauważa się w Polsce systematyczny wzrost wskaźnika communicantes. Przyjmując okresy czasowe wyróżnione przy omawianiu spadku dominicantes, przedstawia się on następująco: 7,8\%$10,7 \%$ (1980-1990); 10,8\%-17,6\% (1981-2007); 15,3\%-16,7\% (2008-2009) ${ }^{14}$. Socjologowie próbują wyjaśniać wspomnianą tendencję wzrostową pracą duszpasterską polskich duchownych, akcentujących znaczenie przyjmowania Komunii św. w czasie udziału we mszy św. oraz zachęcających do korzystania z sakramentu pokuty ${ }^{15}$.

ły, że chociaż 64,0\% procent z nich uważa się za katolików, regularnie na mszę św. w każdą niedzielę uczęszcza 4,5\% badanych - zob. Francuskie dominicantes, www.iskk.pl/index.php?view= artickle@ catid=3\%3Anewsflash@id=96\%3Afranc... [data pobrania 29.09.2010].

W Hiszpanii w 1982 r. praktykowało regularnie 41,0\% dorosłych mieszkańców, natomiast w 2006 r. tylko $18,0 \%$. Z kolei w Irlandii w 1982 r. praktykowało 83,0 \% ogółu mieszkańców a w 2006 r. 46,0 \%. Jeżeli chodzi o grupę osób z przedziału wiekowego 18-24 lata, to w Hiszpanii w 1990 r. praktykowało systematycznie $13,0 \%$ z nich, a w 2006 r. tylko 4,0 \%. Bardziej radykalny spadek praktyk nastąpił w Irlandii. W 1990 r. praktykowało 70,0 \% młodzieży, a w 2006 tylko 16,0 \%. - zob. T. S z a w i e 1: Religijna Polska, religijna Europa. „Więź”. R. 51: 2008 nr 9 s. 33-34.

${ }^{13}$ Zob. Dominicantes 2009 - 30 lat badań praktyk religijności w Polsce, www.iskk./pl/index. php?view=article\&catid=38\%3Akosciol-wpolsce@id, [data pobrania 29.09.2010].

${ }^{14}$ Tamże.

${ }^{15}$ G. G u d a s z e w s k i: Statystyka dominicantes $i$ communicantes jako metoda obserwacji $i$ analizy aktywności W: Socjologia życia religijnego w Polsce, dz. cyt., 164-165. 


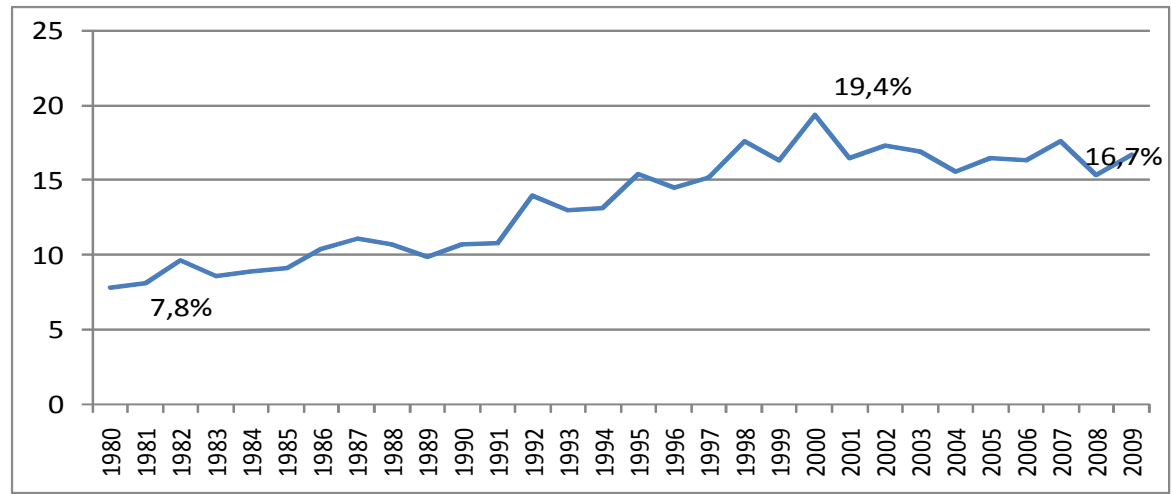

Z sondaży badania opinii publicznej prowadzonych przez różne ośrodki badawcze (CBOS, ISKK SAC) wynika, że nie można ostatecznie formułować tezy o wyraźnym spadku praktyk religijnych, do których należy także msza św. W świetle pozyskanych danych można zaryzykować opinię, że pomimo krótkotrwałych wahań, w społeczeństwie polskim zauważa się zasadniczą ciagłość praktyk religijnych o charakterze obowiązkowym. Janusz Mariański przyjmuje, że utrzymują się one w Polsce na wysokim poziomie - około 60,0\% dorosłych Polaków praktykuje regularnie lub prawie regularnie (w każdą lub prawie w każdą niedzielę), około 15,0\% nieregularnie (raz lub dwa razy w miesiącu). Około 15,0\% populacji ludzi wierzących w Polsce stanowią tzw. katolicy świąteczni (praktykujący z okazji wielkich świąt lub uroczystości rodzinnych), natomiast $10,0 \%$ nie praktykuje w niedzielę lub realizuje jedynie tzw. praktyki jednorazowe (np. chrzest dziecka) ${ }^{16}$.

Wyniki badań socjologicznych ukazujących uczestnictwo we mszy św. w aspekcie ilościowym dostarczają okrojonej wiedzy na temat świadomości religijnej respondentów. Trzeba więc badać wymiary jakościowe uczestnictwa we mszy św., związane między innymi ze świadomością religijną oraz motywacją. Motywacja uczestnictwa w Eucharystii niedzielnej jest złożona i wieloaspektowa. Najogólniej można ją podzielić na motywację religijną i społeczno-

${ }^{16} \mathrm{~J}$. M a ri a ń s ki: Religijność społeczeństwa polskiego $w$ perspektywie europejskiej. Kraków 2004 s. 192-193. 
kulturową. Motywacja religijna związana jest z poszukiwaniem przeżyć religijnych, kontaktem z rzeczywistością transcendentną, spełnianiem nakazu sumienia, wypełnianiem obowiązku wobec Kościoła. Z kolei motywacja społecznokulturowa może się wiązać z potrzebą manifestowania tożsamości grupowej określanej w odniesieniu do społeczeństwa polskiego jako religijność obywatelska, integracyjną funkcją obrzędów religijnych, potrzebą przynależności do struktur społecznych (Kościół, parafia) ${ }^{17}$. Prowadzone przez różne ośrodki badania wykazały, że w większości motywy uczestnictwa we mszy św. niedzielnej były dla badanych osób motywami religijnymi ${ }^{18}$.

Jan Paweł II w swoim liście Dies Domini podkreśla, że jednym z problemów współczesnego świata jest zatracenie pierwotnego sensu niedzieli przez wielu chrześcijan, związanego zarówno z brakiem uczestnictwa w niedzielnej Eucharystii, jak również nieumiejętnością świętowania, którego przejawem jest nie powstrzymywanie się od prac i zajęć nie licujących z istotą tego dnia (zob. DD $4 ; 67)$. Uprawnionym wydaje się postawienie tezy, że zmienia się model świętowania w społeczeństwie polskim, na co ma wpływ kontekst gospodarczy i polityczny. Dyskusja nad modelem świętowania niedzieli obraca się często wokół kwestii robienia w tym dniu zakupów oraz ustawowego zakazu handlu.

Jaki jest stosunek Polaków do robienia zakupów w niedzielę? Z badań przeprowadzonych we wrześniu 2004 r. przez OBOP wynika, że zakupy w niedzielę i święta robiło bardzo często i często 16,0\% respondentów, a rzadko 53,0\% badanych. Nigdy nie robiło zakupów 30,0\% respondentów. Wśród osób robiących często oraz bardzo często zakupy w niedzielę i święta najwięcej było osób młodych (23,0\% badanych w wieku 15-19 lat oraz 20-29 lat), z miast powyżej 500 tyś. mieszkańców $(34,0 \%)$, oceniających swoją sytuację materialną jako dobrą $(27,0 \%)$, określających się jako wierzący, lecz niepraktykujący $(27,0 \%)$ oraz niewierzący $(41,0 \%)$, z wykształceniem wyższym lub średnim (po 21,0\%). Nigdy nie robiły zakupów w niedzielę osoby starsze powyżej 60 lat i więcej $(51,0 \%)$, określające się jako wierzące i regularnie praktykujące $(58,0 \%)$. Z grupy osób określających się jako wierzące i regularnie praktykujące $54,0 \%$ robiło rzadko zakupy w niedziele, $10,0 \%$ czyniło to często, a $34,0 \%$ tego nie czyniło ${ }^{19}$.

Z kolei badania prowadzone przez CBOS w maju 2008 r. wykazały, że w odniesieniu do wyników wcześniejszych sondaży, od 2002 r. nie zmienia się

17 Tamże, s. 204-205; I. B o r o w i k: Procesy instytucjonalizacji i prywatyzacji religii $w$ powojenne Polsce. Kraków 1997 s. 72.

18 J. M a ri a ń s ki: Religijność społeczeństwa polskiego $w$ perspektywie europejskiej, dz. cyt., s. 205-208.

${ }^{19}$ Ośrodek Badania Opinii Publicznej: Czy chcemy kupować w niedziele? Warszawa 2004. www.tns-global.pl [data pobrania 24.09.2010] s. 3-11. 
zasadniczo liczba osób robiących dosyć często i czasami zakupy w niedzielę, których wskaźnik procentowy wynosi 37,0\% (1997 - 16,0\%; $2002-37,0 \%$; $2004-39,0 \%)$. Zwiększyła się natomiast o kilka punktów procentowych liczba osób niezbyt często robiących zakupy w niedzielę, która wynosi 34,0\% (1997 22,0\%; 2002 - 28,0\%; $2004-29,0 \%)$. Od 1997 r. zmniejsza się systematycznie liczba osób nigdy nie robiących zakupów w niedzielę - wskaźnik procentowy tych osób wyniósł w 2008 r. 29,0\% (1997 - 62,0\%; 2002 - 35,0\%; 2004 $32,0 \%)$. Relatywnie najczęściej zakupy robią osoby młodsze, mieszkające w największych aglomeracjach miejskich, lepiej wykształcone, nie uczestniczące w praktykach religijnych bądź praktykujące spontanicznie ${ }^{20}$.

Badania prowadzone przez Instytut Badania Rynku Pentor pokazują, że Polacy stosunkowo rzadko dokonują zakupów w niedzielę. W 2006 r. 39,0\% respondentów deklarowało, że nigdy nie robiło zakupów w niedzielę, 45,0\% przyznawało, że robiło je rzadko (raz na miesiąc lub rzadziej), a 15\% respondentów twierdziło, że robiło je zawsze w niedzielę lub 2-3 razy w miesiącu. Badania pokazały, że odsetek osób nigdy nie robiących zakupów w niedzielę zwiększa się wraz z wiekiem (26,0\% respondentów w wieku do 29 lat nigdy nie robiło zakupów w niedzielę; przy osobach powyżej 50 lat odsetek ten zwiększa się do $56,0 \%)$, a maleje wraz z wykształceniem $(46,0 \%$ respondentów z wykształceniem podstawowym nigdy nie robiło zakupów w niedzielę; ten wskaźnik przy osobach z wykształceniem wyższym wynosi 31,0\%). Najwięcej osób odrzucających robienie zakupów w niedziele mieszka na wsi $(47,0 \%)$, a najmniej w miastach do 50. tysięcy $(27,0 \%)$ i w Warszawie $(36,0 \%)$. Dla tych, którzy nie robili zakupów w niedzielę, dzień ten jest przede wszystkim świętem, dniem świętym $(49,0 \%)$, w którym wypoczywają $(47,0 \%)$. Osoby które dokonują zakupów w niedzielę, za główny motyw swojego działania podają to, że nie mają na nie czasu w ciagu tygodnia (47,0\%). Tylko $11,0 \%$ badanych twierdzi, że jest to dla nich miły sposób spędzenia czasu w niedzielę ${ }^{21}$. Badania prowadzone przez ten sam Instytut w 2010 r. wykazały, że obecnie tylko 2,0\% Polaków chodzi na wielkie zakupy w niedzielę. Instytut podkreśla, że powyższa tendencja ta utrzymuje się od trzech lat ${ }^{22}$.

A jaki jest stosunek Polaków do zakazu handlu w dni świąteczne i niedziele? Pojawiające się propozycje likwidacji handlu w te dni znajdują pewien od-

\footnotetext{
${ }^{20}$ Zob. Centrum Badania Opinii Publicznej: Zachowania konsumenckie. Komunikat z badań. Warszawa 2008. www.cbos.pl [data pobrania 24.09.2010] s. 11-12.

${ }^{21}$ Instytut Badania Rynku Pentor: Stosunek Polaków do handlu w niedziele. Warszawa 2006. www.pentor.pl/main.xml [data pobrania 28.09.2010].

22 Zakaz handlu w niedziele - projekt ustawy NSZZ ,Solidarność”. www.eporady24pl/zakaz handlu w niedzielę - projektustawynszzasolidarność-aktualności,1339.html; [data pobrania 24.09. 2010].
} 
zew w społeczeństwie. Z badań prowadzonych przez Pracownię Badań Społecznych w lutym 2002 r. wynika, że 45,4\% respondentów jest przeciwna zniesieniu handlu w niedzielę, raczej nie odpowiedziało $13,1 \%$; jest to obojętne dla $14,3 \%$ respondentów, raczej tak odpowiedziało $8,2 \%$, nie ma zdania $1,7 \%{ }^{23}$.

Z kolei badania przeprowadzone przez CBOS w październiku 2004 r. wykazały, że wprawdzie tylko $22,0 \%$ respondentów opowiada się za całkowitym zamknięciem sklepów w niedzielę i święta, ale 38,0\% uważa, że należy ograniczyć godziny ich otwarcia Za swobodą działalności handlowej w dni świąteczne, tak jak obecnie, jest 35,0\% badanych. Im wyższy poziom wykształcenia, tym większy odsetek badanych jest za nie ograniczaniem handlu w niedzielę. Na poglądy ma również wpływ, mierzona częstością praktyk, religijność badanych - ponad $50,0 \%$ praktykujących kilka razy w tygodniu jest przeciwna handlowi w dni świąteczne, podczas gdy osoby nie uczestniczące w praktykach religijnych albo biorący w nich udział tylko kilka razy w roku są za utrzymaniem obecnego stanu rzeczy $^{24}$.

Badania prowadzone we wrześniu 2004 r. przez OBOP pokazują, że 54,0\% respondentów jest przeciwna zakazowi handlu w niedzielę, natomiast za takim zakazem dla wszystkich sklepów jest 26,0\% respondentów. Za wprowadzeniem zakazu tylko dla supermarketów i hipermarketów jest 13,0\% badanych. W zdecydowanej większości jest przeciwna wprowadzaniu takiego zakazu grupa osób określająca się jako wierząca, lecz niepraktykująca $(77,0 \%)$ oraz niewierząca $(72,0 \%)$. Wśród osób określających się jako wierzący i regularnie praktykujący 33,0\% respondentów jest za wprowadzeniem zakazu dla wszystkich sklepów, a $43,0 \%$ przeciw wprowadzaniu takiego zakazu. $\mathrm{Z}$ kolei $62,0 \%$ respondentów deklarujących się jako wierzący i nieregularnie praktykujący jest przeciw takiemu zakazowi $^{25}$. Najnowsze badania prowadzone przez Instytut Badania Rynku Pentor w styczniu 2010 r. pokazują, że 77,0\% społeczeństwa sprzeciwia się niedzielnemu handlowi, co stanowi wzrost takich postaw od 2008 o $22,0 \%{ }^{26}$.

Zestawienie przytoczonych wyników badań dotyczących robienia przez Polaków zakupów w niedziele i stosunku do zakazu handlu w tym dniu, przepro-

\footnotetext{
${ }^{23}$ Sondaż PBS: Zakupy w niedziele. Sopot 2002. www.wiadomości.polska.pl/spoleczentwo/ article,Sondaz,id,5779.htm [data pobrania 7.04.2009].

${ }^{24}$ Centrum Badania Opinii Społecznej: Zakupy - gdzie i co kupujemy. Komunikat z badań. Warszawa 2004. www.cbos.pl [data pobrania 20.03.2009] s. 9-10.

${ }^{25}$ Ośrodek Badania Opinii Społecznej Omnias, Czy chcemy kupować w niedzielę? Warszawa 2004, www.tns-global.pl [data pobrania 20.03.2009] s. 4-5.

${ }^{26}$ Zakaz handlu w niedziele - projekt ustawy NSZZ ,Solidarność”/. www.eporady24pl/zakaz handlu w niedzielę - projektustawynszzasolidarność-aktualności,1339.html; [data pobrania 24.09.2010].
} 
wadzonych przez różne instytuty badawcze, wskazuje na pewne różnice. Są one szczególnie widoczne w wynikach badań prowadzonych przez CBOS i Instytut Badania Rynku Pentor. Trudno znaleźć jednoznaczną przyczynę powstałych rozbieżności. Należą do nich między innymi: zastosowana metoda badawcza, dobór próby oraz sposób i forma zadanych pytań. Dla bardziej obiektywnego spojrzenia na tego typu problemy, należy zwracać uwagę na metodologię prowadzonych badań, wykorzystując i zestawiając materiał pozyskany z różnych źródeł.

Mimo pojawiającej się różnicy w wynikach uzyskanych badań, można, odwołując się także do obserwacji uczestniczqcej, stwierdzić, że w świadomości i postawie coraz większej liczby osób zanika sakralne znaczenie Dnia Pańskiego. Następuje desakralizacja niedzieli jako dnia świętego przeznaczonego dla Boga i na odpoczynek. Co prawda procentowy wskaźnik osób uczęszczających na mszę św. pozostaje zasadniczo niezmienny, nie zadawala jednak fakt, że w społeczeństwie, w którym od 93,0\% do 97,0\% obywateli deklaruje się jako osoby wierzą$\mathrm{ce}^{27}$, tylko czesść $\mathrm{z}$ nich regularnie praktykuje. W świetle prowadzonych badań można też stwierdzić, że łamane są zasady religijnego świętowania niedzieli przez przeżywanie jej w duchu świeckim, jak też często nie ma przełożenia deklarowanej wiary i praktyk na postawy moralne ${ }^{28}$. Polacy nie zawsze właściwie przestrzegają przykazanie Pamiętaj abyś dzień święty święcit, „,pielgrzymując” w niedziele do, będących współczesnymi światyniami konsumpcjonizmu, centrów handlowych i hipermarketów ${ }^{29}$. Zachodzące w Polsce procesy sekularyzacyjne,

${ }^{27}$ CBOS: Dwie dekady przemian religijności w Polsce. Warszawa 2009. www.cbos.pl [data pobrania 2.10.2010].

${ }^{28} \mathrm{~J}$. B a n i a k wykazuje, że na przestrzeni lat zmienia się nastawienie polskich katolików, szczególnie zamieszkujących środowiska miejskie, do niedzieli, widzących w niej jedynie zwykły dzień, pozbawiając go charakteru sakralnego i świąteczno-religijnego. Przejawia się to nie tylko we wzrastającym braku udziału w niedzielnej mszy św., ale również w laickim stylu spędzania niedzieli, który eliminuje sacrum z życia osobistego i rodzinnego. J. M a r i a ń s k i podkreśla, że chociaż w Polsce nie można mówić o wzroście czy spadku praktyk religijnych, zwłaszcza niedzielnych, to jednak zauważa się zachodzące zmiany w świadomości religijnej Polaków dotyczące osłabienia motywacji ich praktyk religijnych oraz nie podzielania przez nich wartości głoszonych przez Kościól, szczególnie dotyczących postaw moralnych (rozdzielenie seksu i prokreacji, współżycie przedmałżeńskie, zwiększająca się aprobata stosowania środków antykoncepcyjnych, rozwody, aborcja). Widoczne jest przechodzenie od chrześcijańskiego systemu wartości i norm do bliżej nieokreślonego lub wręcz laickiego systemu wartości - zob. J. B a n i a k: Desakralizacja kultu religijnego i świqt religijnych w Polsce. Studium socjologiczne. Kraków 2007 s. 37-63; J. M a r i a ń s k i: Religijność społeczeństwa polskiego w perspektywie europejskiej, dz. cyt., s. 244-246; $372-378$.

${ }^{29}$ Warto zapoznać się z artykułem Weroniki Ś 1 ę z a k - T a z b i r ukazującym konsumpcję jako rodzaj nowej religii $\mathrm{w}$ zsekularyzowanym świecie. Autorka w bardzo przemyślany sposób ukazała, jak dotychczasowe funkcje religijne świątyń są obecnie realizowane przez hipermarkety i 
wyrażające się między innymi w zatraceniu rozumienia istoty niedzieli i jej sakralnego charakteru, stają się przyczyną zmian modelu świętowania.

W świetle przeprowadzonych badań trudno udzielić jednoznacznej odpowiedzi na pytania dotyczące rozmiarów kryzysu świętowanie niedzieli w Polsce. Są dane socjologiczne świadczące o symptomach takiego kryzysu, inne z kolei wprost go nie potwierdzają. Chyba jeszcze za wcześnie na stawianie tezy o poważnym kryzysie religijności społeczeństwa polskiego, w tym również świętowania niedzieli. Uzyskane dane można interpretować jako pewne zwiastuny zachodzących zmian. Faktem jest, iż religijność polskiego społeczeństwa podlega tym samym procesom przemian, co głęboko zsekularyzowane społeczeństwa Europy Zachodniej. Nie można jednak z całą pewnością twierdzić, że zachodzące obecnie procesy spowodują masowe odwrócenie się Polaków od religii oraz Kościoła. Janusz Mariański, analizując zmieniającą się polską religijność i stawiając różne hipotezy dotyczące jej zmian, prognozuje, że dojdzie do wielokierunkowych jej przemian, które z jednej strony będą związane $\mathrm{z}$ silnie zachodzącymi procesami sekularyzacyjnymi i nieco słabszymi procesami indywidualizacyjnymi społeczeństwa, religii i rodziny, a z drugiej z szerokimi wpływami ewangelizacyjnymi Kościoła ${ }^{30}$.

Teolog pastoralista, dialogując $\mathrm{z}$ socjologiem, nie tylko korzysta $\mathrm{z}$ diagnoz pewnych zjawisk i postaw, ale także sięga do prognoz stawianych przez nauki społeczne. Wśród nich znajduje się demografia, która zajmuje się badaniem liczebności i struktur ludności oraz zmianami związanymi z ruchem naturalnym i wędrówkowym społeczeństw. Jest to osobna dziedzina, która z socjologią dzieli metodę statystyczną oraz przedmiot badań. To dzięki temu powiązaniu socjologia bez oporów metodologicznych może i chętnie sięga do argumentów demograficznych, aby wyjaśniać zjawiska i procesy społeczne, zarówno dotyczące rzeczywistości przeszłej, obecnej, jak i przyszłej ${ }^{31}$. Przyszłą rzeczywistość, co istotne w podejmowanej problematyce, kształtuje się teoretycznie dzięki prognozom, których zadaniem jest przewidywanie najbardziej prawdopodobnego przebiegu zdarzeń. W sposób racjonalny i najbardziej dokładny może ona dotyczyć najbliższych $10-15$ lat. W takiej sytuacji jest ona oparta na prognozie biologicznej i migracyjnej, które uwzględniają natężenie przyszłych urodzeń i zgonów przy równoległym uwzględnieniu zmian warunków społeczno-gospodarczych, w poziomie i dostępności służby zdrowia, oświaty itp. Jest to najtrudniejsze zada-

centra handlowe - zob. W. Ś 1 ę z a k - T a z b i r: Kupujac sens życia. Konsumpcja jako nowa religia w zsekularyzowanym świecie. „Socjologia Religii”. T. 4: 2006 s. 249-261.

${ }^{30} \mathrm{~J}$. M a ri a ń s ki: Katolicyzm polski w perspektywie europejskiej: misja czy przystosowanie, czyli z jakq religijnościq do Europy. „Socjologia Religii”. T. 2: 2004 s. 63-69.

${ }^{31}$ K. K 1 u z o w a: Demografia. W: Encyklopedia socjologii. T. 1 (A-J). Warszawa $1998 \mathrm{s.}$ 115-119. 
nie w całym procesie prognozowania, zbliżając je do drugiej metody - projekcji studialnej. Ma ona czysto hipotetycznie ustalić kierunek zmian w stanie i strukturze ludności według płci i wieku.

Obiema metodami posługuje się Główny Urząd Statystyczny przygotowujący coroczne raporty na temat struktury społeczeństwa polskiego. Według ekspertów tego instytutu, wyniki badań nie są pocieszające i należy szybko na nie reagować. Okazuje się bowiem, że w ciagu najbliższych 20. lat struktura ta będzie się zmieniała w kierunku układu regresywnego, gdzie przy rosnącej liczbie osób starszych, maleć będzie liczba urodzeń. W tym czasie bowiem przewiduje się znaczny wzrost długości trwania życia. O ile w 2007 r. wynosił on w Polsce 71 lat dla mężczyzn i 79 lat dla kobiet, to w 2030 r. osiagnie poziom odpowiednio 75,8 i 82,2. Nie jest to jednak optimum, jakie może osiągnąc społeczeństwo polskie, skoro już w 2007 r. na Islandii i w Szwajcarii współczynnik ten wynosił 79,5 - mężczyźni i ponad 83 - kobiety ${ }^{32}$. Przeciętny Polak będzie żył dłużej, ale mimo tego nie zostanie zahamowane zmniejszanie się liczby ludności Polski. Według przewidywań, spadnie ona w ciagu tych dwudziestu lat z $38.167 \mathrm{mln} w$ 2010 r. do 36.796 mln w 2030 r. $^{33}$.

Warto przyjrzeć się bardziej szczegółowo tym przewidywaniom. Analiza biologicznych grup wieku wskazuje na to, że w 2030 r. wzrośnie liczba osób w podeszłym wieku, zaś diametralnie zmniejszy się odsetek osób w wieku reproduktywnym i aktywnym zawodowo. Poszukiwanie odpowiedzi na te prognozy pozwoli ukazać ogólne tendencje dotyczące kondycji demograficznej społeczeństwa polskiego i jej przyczyn.

\begin{tabular}{|c|c|c|c|c|c|}
\hline Wiek & $\mathbf{2 0 1 0}$ & $\mathbf{2 0 1 5}$ & $\mathbf{2 0 2 0}$ & $\mathbf{2 0 2 5}$ & $\mathbf{2 0 3 0}$ \\
\hline $\mathbf{0 - 1 4}$ & 15,0 & 15,2 & 15,6 & 15,0 & 13,7 \\
\hline $\mathbf{1 5 - 6 4}$ & 71,4 & 69,2 & 66,0 & 64,1 & 64,0 \\
\hline $\mathbf{6 5 +}$ & 13,5 & 15,6 & 18,4 & 21,0 & 22,3 \\
\hline $\mathbf{8 0 +}$ & 3,5 & 3,9 & 4,1 & 4,1 & 5,5 \\
\hline
\end{tabular}

Tab. 1. Prognozowany rozkład wieku w Polsce w latach 2010-2030. Źródło: GUS

${ }^{32}$ GUS: Rocznik Demograficzny 2009. Warszawa 2009 s. 500-503.

${ }^{33}$ Warto zauważyć, że według prognoz z 2007 r. ludność Polski w 2010 r. miała być mniejsza od stanu faktycznego o 75 tysięcy. Prognozy te różnią się nieco w zależności od ośrodka badawczego. Według Eurostatu ten spadek będzie nieco mniejszy, zaś ONZ wylicza, że Polaków będzie $35.353 \mathrm{mln}$. Prognozy te różnią się także przy innych współczynnikach. Analizy ONZ były tworzone w 2004 r., kiedy pozytywna tendencja dzietności kobiet dopiero zaczęła być wyraźna zob. GUS: Prognoza ludności na lata 2008-2035. Warszawa 2009 s. 187-188; GUS: Rocznik Demograficzny 2009, dz. cyt., s. 167. 
Pozostając przy rozkładzie wiekowym społeczeństwa polskiego, warto odnotować, że już teraz duży udział statystyczny w społeczeństwie mają osoby starsze. O wielkości tego udziału niech wskazuje fakt, że współczynnik feminizacji, który obecnie jest na poziomie mniej więcej 107 (nadwyżka kobiet nad mężczyznami) i nie zmieni się znacząco do 2030 r., jest kształtowany przede wszystkim przez ludzi starszych. Oto prawie do końca wieku produkcyjnego więcej jest mężczyzn niż kobiet. Dopiero po 45. roku życia tendencja się odwraca, aby osiagnąć współczynnik feminizacji 240 dla osób powyżej 80 . lat ${ }^{34}$.

Skoro tak znacznie wzrasta ilość osób starszych, nie można liczyć na to, że społeczeństwo będzie się chętnie przemieszczało na stałe, choćby w kraju, co w demografii nazywane jest migracją wewnętrzną. O ile bowiem przewiduje się, że w 2010 r. na stałe zmieni swe miejsce zamieszkania 533 tysięcy osób, to w 2030 r. będzie już ich tylko 420 tysięcy, z czego $2 / 3$ przeniesie się na stałe do miast. Podobnie zmniejszać się będzie także współczynnik migracji zagranicznych. W 2030 r. na stałe wyjedzie z Polski 20 tysięcy osób, to jest dwa razy mniej niż obecnie. Według prognoz w tym samym roku powróci do kraju 30 tysięcy osób, czyli o $1 / 3$ więcej niż wraca obecnie. Ten ruch migracyjny znacznie intensywniej odbywa się w miastach niż na wsi ${ }^{35}$. Zmniejszający się współczynnik migracji jest efektem zmniejszania się ludności Polski, zwłaszcza osób w wieku mobilnym, czyli produkcyjnym. Oczywiście ruch ten zależy przede wszystkim od sytuacji społeczno-gospodarczej kraju, jego polityki migracyjnej i sytuacji na rynku pracy w całej Unii Europejskiej. Dlatego tak trudno przewidywać, jakie tendencje przyjmie ruch migracyjny w ciągu tych 20 lat w rzeczywistości. Można się spodziewać, że znacznie mniej osób chętnych będzie do wyjazdu, gdy będą one miały stabilną sytuację rodzinną i materialną. A co istotne, przy migracjach wewnętrznych dochodzi także czynnik zawieranych małżeństw, bowiem wielokrotnie wejście w związek wiąże się z przeprowadzką do innej miejscowości.

Zmieni się także tendencja przyrostu naturalnego w Polsce, który mimo obecnie dodatniego wyniku, za kilka lat z powrotem odwróci swój wskaźnik. O ile obecnie jest na poziomie 13 tysięcy nadwyżki urodzeń nad zgonami, za 20 lat zgonów będzie już 154 tysiące więcej niż urodzeń. Co ciekawe, wieś przez cały powojenny czas ma przyrost naturalny dodatni. Zmieni się to jednak około 2020 r., kiedy więcej osób będzie umierało niż się rodziło.

\footnotetext{
${ }^{34}$ GUS: Prognoza ludności na lata 2008-2035, dz. cyt., s. 159.

${ }^{35}$ Tamże, tablica 4.
} 


\begin{tabular}{|c|c|c|c|c|}
\hline $\mathbf{2 0 1 0}$ & $\mathbf{2 0 1 5}$ & $\mathbf{2 0 2 0}$ & $\mathbf{2 0 2 5}$ & $\mathbf{2 0 3 0}$ \\
\hline 13002 & -10006 & -56092 & -109916 & -154803 \\
\hline
\end{tabular}

Tab. 2. Prognozowany rozkład przyrostu naturalnego na lata 2010-2030. Źródto: GUS

Sygnalizowana tendencja wynika między innymi ze zmniejszania się liczebności kobiet $\mathrm{w}$ wieku rozrodczym, gdyż przyszłe matki pochodzą z pokolenia niżu demograficznego. Poza tym, wydłuża się dalsze trwanie życia i zmienia proces umieralności społeczeństwa.

W obecnych latach także, do 2012 r., rodzi się najwięcej dzieci, co wynika z kilku głównych przesłanek. W poprzednich dekadach rodziło się znacznie mniej dzieci, co jest związane z sytuacją transformacji, która zmniejsza w ogóle dzietność społeczeństw. Obecnie na rodzenie zdecydowały się kobiety z końca wyżu demograficznego. Odroczyły one bowiem moment zawarcia małżeństwa na wiek 25-29 lat. Ponieważ wciąż najwięcej dzieci rodzi się w małżeństwach, przesunął się i podwyższył średni wiek ich rodzenia. Dlatego, o ile w 2010 r. kobieta w mieście rodzi w wieku 29,13 a mieszkanka wsi w wieku 28,49, to za dwadzieścia lat obie kobiety urodzą 1,5 roku później ${ }^{36}$. Za to, jak się wydaje, będą one miały więcej dzieci, gdyż współczynnik dzietności powoli zwiększy się z 1,28 (miasto) i 1,47 (wieś) do odpowiednio 1,43 i 1,47. Jak wskazują demografowie, współczynnik dzietności powinien się na tym poziomie ustabilizować ${ }^{37}$. Niepokojący jest jednak fakt, że nieustannie rośnie liczba urodzeń pozamałżeńskich. Łączy się to $\mathrm{z}$ innym spostrzeżeniem demografów, że od lat spada ogólna liczba zawartych małżeństw, a rośnie liczba rozwodów. Na marginesie należy zauważyć, że mimo tego, na tle Europy, Polska pozostaje krajem o małej deinstytucjonalizacji rodziny i konwencjonalnym jej tworzeniu, a negatywne procesy nasiliły się dopiero w fazie transformacji ${ }^{38}$. To zapewne między innymi dlatego współczesna młodzież odracza decyzje matrymonialne, a założenie rodziny, jako cel życiowy, stawia na trzecim miejscu, po wykształceniu i karierze zawodowej ${ }^{39}$.

Zaprezentowane powyżej kwestie nie napawają zbytnim optymizmem, zwłaszcza że obserwuje się ich znaczną intensywność na obszarze Polski. Wynika to przede wszystkim z sytuacji konfliktu kulturowego, przed którym stanęli Polacy podczas przemian ustrojowych. Tradycyjne pojmowanie ról społecznych, choćby kobiety, musiało został skonfrontowane z oczekiwanymi przez społeczeństwo europejskie nowymi wyzwaniami. Malejąca liczba zawieranych związ-

\footnotetext{
${ }^{36}$ Tamże, tablica 2.

${ }^{37}$ Tamże, tablica 1.

${ }^{38}$ Polska 2030. Wyzwania rozwojowe. Red. M. B o n i. Warszawa 2009 s. 51-63.

${ }^{39} \mathrm{~K} . \mathrm{P}$ a w 1 i n a: Mtodzież szkolna o swoich problemach. Warszawa 2010 s. 37.
} 
ków, znaczny ich rozpad poprzez rozwód czy separację prowadzą do opóźniania bądź zaniechania zakładania rodziny. Decyzje reprodukcyjne są odkładane w czasie, co nie oznacza, że ich w ogóle nie ma. W tym okresie coraz większy wpływ na decyzje młodych będzie miał rozwój gospodarczy, sytuacja materialna rodzin oraz polityka rodzinna, która powinna rozwijać swój zakres usług społecznych.

Najbliższe lata postawią młodych przed nowym wyzwaniem, które także wynika ze zmian w strukturze demograficznej społeczeństwa. Prognozy o starzejącym się społeczeństwie wymagają nowego spojrzenia na miejsce osób starszych. Benedykt XVI w swoim wystapieniu 18 września 2010 r. podczas wizyty w Domu dla osób starszych pod wezwaniem św. Piotra w Londynie zauważył, że to zjawisko jest efektem wydłużania się życia ludzkiego, które jest podtrzymywane dzięki postępowi w medycynie. Fakt ten trzeba wykorzystać jak najlepiej do kształtowania kolejnych pokoleń. Dla papieża osoby starsze są błogosławieństwem, gdyż mogą uczyć ze swych doświadczeń i mądrości ${ }^{40}$. Z taką opinią zgadza się 87,0\% polskiego społeczeństwa, które w 2008 r. stwierdziło w badaniu CBOS, że ludzie starsi są potrzebni społeczeństwu ${ }^{41}$. Zwraca się uwagę przede wszystkim na pomoc w wychowaniu, jaką można uzyskać od osób starszych ${ }^{42}$. $\mathrm{W}$ wielu regionach to właśnie $\mathrm{w}$ środowisku ludzi starszych dokonuje się pierwotna socjalizacja religijna. To oni ze swym bogatym bagażem przeżyć religijnych, przemyśleń, obserwacji, stanowią kapitał społeczny, którego nie można przecenić. Na ten aspekt wskazuje dokument Papieskiej Rady do Spraw Świeckich Godność i postannictwo ludzi starszych w Kościele i świecie ${ }^{43}$. Dokument ten stanowi kompendium nauczania Kościoła na temat osób starszych i ich duszpasterstwa. Duszpasterstwo osób w podeszłym wieku powinno między innymi rozwijać się w oparciu o podstawowe zasady społeczne wypracowane przez katolicką naukę społeczną: solidarność, troskę o dobro wspólne i wzajemną pomoc. Wszystkie prowadzone działania mają zmierzać do tego, by upodmiotowić i zaktywizować osoby starsze $\mathrm{w}$ duszpasterstwie. Mają one wzbogacać proces humanizacji społeczeństwa i kultury przez korzystanie z charyzmatu starości ${ }^{44}$. Dla zapewnienia duszpasterskiej opieki nad ludźmi starszymi potrzeba odpo-

\footnotetext{
${ }^{40}$ B e n e d y k t X V I: Wystapienie podczas wizyty w Domu dla osób starszych pw. św. Piotra. Londyn, 18. września 2010 r. „Wiadomości KAI”. R. 2010 nr 38 s. 31.

${ }^{41}$ CBOS: Polacy wobec ludzi starszych $i$ wtasnej starości. Warszawa 2009 s. 1.

${ }^{42} 97,0 \%$ respondentów uważało, że maja czas dla wnuków, podczas gdy rodzice intensywnie pracuja, zaś 95,0\%, że majq istotne doświadczenie $i$ wiedze, której brakuje ludziom młodszym zob. CBOS: Polacy wobec ludzi starszych i wtasnej starości, dz. cyt., s. 3.

${ }^{43}$ Papieska Rada do Spraw Świeckich: Godność i postannictwo ludzi starszych w Kościele $i$ świecie. Watykan 1998.

${ }^{44}$ Tamże, s. 251.
} 
wiednio przygotowanych osób duchownych i świeckich ${ }^{45}$, którzy będą między innymi uwrażliwiać środowiska parafii i społeczności lokalnych na los seniorów. W tej kwestii szczególną rolę mają do odegrania media, które mogą zmieniać nastawienie do okresu jesieni życia, zarówno społeczeństwa jak i samych osób starszych. Jednym z głównych zadań Kościoła jest walka z propagowaniem eutanazji będącej poważnym naruszaniem prawa Bożego (EV 65). Cechą cywilizacji ludzkiej jest szacunek $i$ mitość do ludzi starych, dzięki którym mogq oni czuć się, mimo stabnacych sit, żywa częściq społeczeństwa ${ }^{46}$.

\section{Postawy różnych środowisk wobec ludzi starszych}

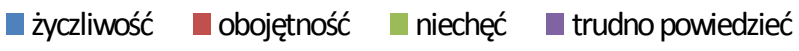

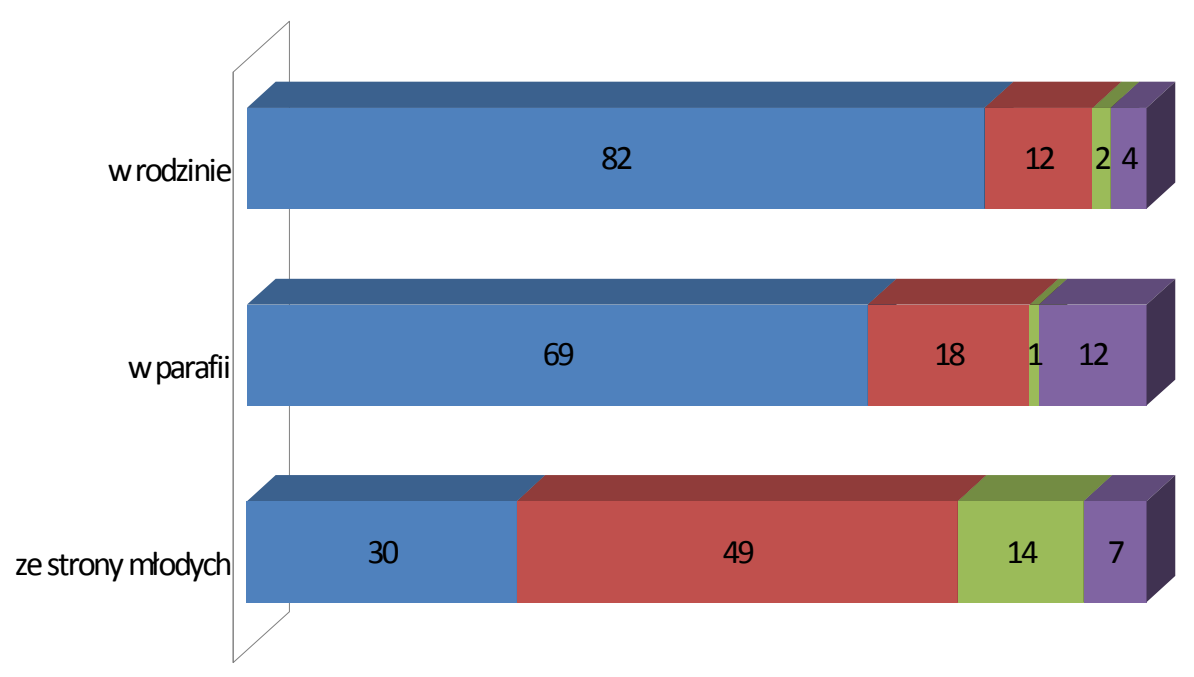

Wykres 3. Postrzeganie postaw różnych środowisk wobec ludzi starszych. Dane w \%. Źródto: $C B O S$

\footnotetext{
${ }^{45}$ Tamże, s. 259.

${ }^{46}$ J a n P a w e $\nmid$ I I: List do ludzi w podesztym wieku. Watykan 1999 pkt 12.
} 
Czy to wskazanie Magisterium jest dostatecznie realizowane w społeczeństwie polskim? Jak wynika $\mathrm{z}$ badań przeprowadzonych przez CBOS $\mathrm{w}$ listopadzie 2009 r. 64,0\% respondentów uznało, że w polskim społeczeństwie szanuje się starszych, podczas gdy aż $31,0 \%$ było odmiennego zdania ${ }^{47}$. Z odpowiedzi respondentów wynika, że postawa wobec ludzi starszych zależy od danego środowiska.

Z przytoczonych wyników badań jasno wynika, że największą życzliwością ludzie starzy cieszą się w rodzinach $(82,0 \%)$ i w parafii $(69,0 \%)$, a z kolei z największą obojętnością spotykają się ze strony młodzieży (49,0 \%). Uzyskane wyniki badań wskazują na konieczność podjęcia pewnych działań, które z jednej strony umocnią tendencje pozytywne, a $\mathrm{z}$ drugiej wpłyną na zmianę stosunku młodzieży do ludzi starych.

W trakcie dotychczasowych rozważań przedstawiono wyniki badań socjologicznych dotyczących symptomów kryzysu świętowania niedzieli oraz starzenia się społeczeństwa. Zostały one ukazane w łączności z zasygnalizowanymi w sposób skrótowy wskazaniami Magisterium Kościoła dotyczącymi poruszanej problematyki. Taki układ treści jest odzwierciedleniem jednego z paradygmatów stosowanych $\mathrm{w}$ teologii pastoralnej. Został on ujęty w formie sylogizmu praktycznego, w którym przesłankę większą stanowi zasada objawiona, przesłanką mniejszą są dane dostarczone przez badania socjologiczne, psychologiczne, a wnioskiem postulaty odnoszące się do działalności pastoralnej ${ }^{48}$. W myśl tego paradygmatu, czas teraz na zaproponowanie pewnych kierunków działań dla Kościoła w Polsce.

\section{Odpowiedź Kościoła w Polsce na zdiagnozowane i prognozowane znaki czasu}

Po przedstawieniu diagnozy dotyczącej świętowania niedzieli i prognozy starzenia się społeczeństwa, pragniemy teraz przedstawić pewne propozycje działań, które powinien podjąć w swojej pracy duszpasterskiej Kościół w Polsce. Ich kierunek wyznacza z jednej strony wierność Objawieniu i Magisterium Kościoła, a z drugiej strony uwzględnienie uwarunkowań działalności duszpasterskiej, ukazanych z wykorzystaniem danych statystycznych. Nasze propozycje nie wyczerpują całościowo poruszanej problematyki, ale mają tylko charakter kierunkowy, sygnalizując pewne zagadnienia. Pisząc o dialogu między teologią pastoralną i socjologią, nie może zabraknąć konkretnego owocu tego dialogu,

\footnotetext{
${ }^{47}$ CBOS: Polacy wobec ludzi starszych i wtasnej starości, dz. cyt., s. 4.

${ }^{48}$ W. Przyg od a: Paradygmaty metodologiczne we wspótczesnej teologii pastoralnej. „Teologia Praktyczna”. T. 10: 2009 s. 36-39.
} 
którym będzie etap prakseologiczny, obejmujący wskazania i postulaty urzeczywistniania się Kościoła na przyszłość.

Z przywoływanych wyników badań dotyczących świętowania niedzieli w Polsce wynika, że nie można w sposób katastroficzny formułować tezy o głębokim kryzysie przeżywania tego dnia. Dotyczy to zarówno uczestnictwa we mszy św. niedzielnej, jak też stosunku do robienia zakupów w niedzielę oraz ustawowego zakazu handlu. Prowadzone w dłuższej perspektywie przez różne ośrodki badania dotyczące uczestnictwa we mszy św. niedzielnej pokazują, że pomimo krótkotrwałych wahań, zauważa się zasadniczą ciągłość tej praktyki religijnej w polskim społeczeństwie. Niektórzy socjologowie uważają, że proces sekularyzacji, rozumiany w jego wąskim znaczeniu jako „odkościelnienie” (zerwanie więzi z Kościołem instytucjonalnym przez zaprzestanie lub wyraźne ograniczenie uczestnictwa w praktykach religijnych), nie ma jeszcze miejsca w Polsce ${ }^{49}$. Większy niepokój budzi sposób świętowania niedzieli przez Polaków, wśród których spora grupa osób robi zakupy w niedzielę i jest przeciwna ustawowemu zakazowi takiego handlu. Trudno w świetle przytoczonych wyników badań dokładnie określić zakres tych zjawisk, gdyż zauważa się różnice w danych publikowanych przez różne ośrodki badawcze.

Patrząc całościowo na uzyskane wyniki badań, trzeba jednak odczytać je jako pewien sygnał ostrzegawczy, mówiący o postępującej zmianie sposobu świętowania niedzieli przez polskich katolików. Powinno to pobudzić do podejmowania inicjatyw duszpasterskich na płaszczyźnie wychowawczej, duchowej i społecznej, pomagających przeżywać niedzielę zgodnie z jej prawdziwym sensem, o co apelował Jan Paweł II w adhortacji apostolskiej Ecclesia in Europa (zob. EiE 81). Buduje fakt, że myśl zawarta w nauczaniu Kościoła Powszechnego znalazła swoje odzwierciedlenie w nowym Programie Duszpasterskim dla Kościoła w Polsce na lata 2010-2013 KoŚCióŁ DOMEM I SZKOŁĄ KOMUNII. W całym trzyletnim cyklu programu przewiduje się też inspirowanie w różnych środowiskach dyskusji na temat oblicza niedzieli. Twórcy programu zakładają stworzenie w ciągu trzech lat koalicji podmiotów zatroskanych o to, aby niedziela przeżywana jako Dzień Pański była dniem dla rodziny, wypoczynku i zaangażowania społecznego ${ }^{50}$.

${ }^{49}$ R. B o g u s z e w s k i: Polak - na zawsze katolik? Polska religijność w latach 1998-2008 na podstawie badań CBOS, dz. cyt., s. 23-24.

${ }^{50}$ Komisja Duszpasterstwa Konferencji Episkopatu Polski: W komunii z Bogiem. Kościół domem i szkoła komunii. Program duszpasterski Kościoła w Polsce na lata 2010-2013 Red. Sz. S t u ł k o w s ki. Poznań 2010 s. 17.

W Austrii działa Sojusz na rzecz wolnej niedzieli, będący organizacją pozarządową skupiającą ugrupowania (kościoły, związki zawodowe, stowarzyszenia, izby gospodarcze, grupy interesu, ruchy społeczne) podejmujące działania na rzecz prawnej obrony niedzieli i świąt. Zasadami okre- 
Jakie konkretne działania należy podjąć w Polsce aby przywrócić sens niedzieli?

- Nieustanne propagowanie, z wykorzystaniem między innymi mass mediów (rola Internetu!), treści zawartych w dokumentach Magisterium Kościoła dotyczących teologicznego znaczenia dnia Pańskiego, obejmujących zarówno jego wymiar wertykalny, jak i horyzontalny.

- Pogłębianie motywacji postaw - uczestnictwo w niedzielnej Eucharystii nie może być ukazywane jedynie jako konieczność jurydycznego wypełniania III przykazania Dekalogu, ale jako konkretna odpowiedź na miłość Boga, która najpełniej objawia się w tym sakramencie. Trzeba nieustannie ukazywać sens odpoczynku, jak również pracy ludzkiej, podkreślając, że człowiek nie może stać się jej niewolnikiem, traktując ją w sposób bałwochwalczy ${ }^{51}$. Z przytoczonych wyników badań wynika, że tego typu działania powinny być w sposób szczególny podejmowane wobec osób młodych, mieszkających w dużych miastach, mających wyższe wykształcenie i niezbyt regularnie wypełniających praktyki religijne.

- Ars celebrandi - fundamentalne znaczenie w formowaniu postaw do właściwego przeżywania niedzieli odgrywa dobre przygotowanie i celebrowanie niedzielnej Eucharystii z udziałem odpowiednio uformowanego laikatu.

- Podejmowanie wysiłków prowadzących do tego, aby prawo państwowe gwarantowało prawo człowieka do odpoczynku oraz propagowanie inicjatyw zmierzających do ustawowego zakazu lub ograniczenia handlu w niedzielę. Do

ślającymi profil Sojuszu są ponadpartyjność, pluralizm światopoglądowy, niezależność od instancji państwowych. Jego regularne działania sprowadzają się do kształtowania świadomości społecznej (działania medialne, kampanie społeczne, materiały informacyjne), lobbingu politycznego, zajmowania stanowiska wobec wspomnianej kwestii.

Warto w tym miejscu wspomnieć też o dokumencie Komisji Episkopatów Wspólnoty Europejskiej z 6 września 2008 r. wzywającym Parlament Europejski do podjęcia debaty o pracy w niedzielę i zawierającym postulat, aby w dyskutowanej obecnie nowej wersji Dyrektyw o czasie pracy zapisać punkt, że czas cotygodniowego odpoczynku powinien obejmować niedzielę.

W Polsce 1 lutego 2008 r. podpisano Przymierze na rzecz wolnej niedzieli sygnowane przez 21. przedstawicieli organizacji pozarządowych, stowarzyszeń pracodawców i związków zawodowych. Najważniejszym celem przymierza jest dążenie do zachowanie świątecznego charakteru niedzieli jako dnia wolnego od pracy. Zwolennicy idei wolnych niedzieli chcą przez kampanie społeczne doprowadzić do uregulowań prawnych, w tym zapisu konstytucyjnego, określającego niedzielę jako dzień wolny od pracy - zob. Ju: Podpisano »Przymierze na rzecz wolnej niedzieli«. „Wiadomości KAI”. R. 2008 nr 7 s. 4.

${ }^{51}$ Konstytucja duszpasterska o Kościele II Soboru Watykańskiego Gaudium et spes, mówiąc o pracy, podkreśla, że wszyscy powinni cieszyć się wypoczynkiem i czasem wolnym wystarczającym do prowadzenia życia rodzinnego, kulturalnego, spotecznego i religijnego (KDK 67). Z kolei J a n $\mathrm{P}$ a w e 1 I I w encyklice o pracy ludzkiej Laborem exercens pisze, że człowiek jest podmiotem pracy (LE 6). Według papieża człowiek ma naśladować Boga pracując i odpoczywając co siódmy dzień (LE 25). 
tych działań trzeba włączać nie tylko katolików, ale ludzi innych wyznań oraz niewierzących, wskazując, iż chodzi o niedzielę jako dobro publiczne i wartość kulturową ${ }^{52}$.

A jakie zadania powinien podjąć Kościół w Polsce w obliczu faktu starzenia się społeczeństwa?

- Wyjaśnianie istoty IV przykazania Dekalogu, szczególnie w odniesieniu do ludzi starszych, oraz propagowanie nauczania Magisterium dotyczącego szacunku wobec tej grupy osób (rola homilii, katechezy, propagowanie idei wolontariatu). Problematykę tę winien uwzględniać wieloletni program duszpasterski konstruowany przez Komisję Duszpasterstwa Konferencji Episkopatu Polski.

- Podkreślanie roli sakramentów w życiu ludzi starych, których długość życia się nieustannie zwiększa (zmiana świadomości dotyczącej roli sakramentu namaszczenia chorych, umożliwianie korzystania z posługi nadzwyczajnych szafarzy Komunii świętej).

- Podejmowanie działań zmierzających do zmiany świadomości społeczeństwa, w tym ludzi starych, na temat znaczenia starości w życiu Kościoła i innych wspólnot. Należy zwracać uwagę na wartość komunikacji międzypokoleniowej i jej znaczenie w przekazie wartości, kultury, norm i obyczajów. Konieczne jest przeciwstawianie się eutanazji.

- Wykorzystanie czasu, potencjału i doświadczenia ludzi starszych w duszpasterstwie, zwłaszcza w pracach różnego rodzaju rad i wspólnot.

- Przytoczone prognozy wskazują na zwiększająca się grupę osób w wieku poprodukcyjnym, potrzebna więc będzie współpraca Kościoła i państwa w kreowaniu polityki prorodzinnej (podatki, stabilność ekonomiczna rodzin) oraz w uwrażliwianiu na wielorakie potrzeby ludzi starych (współpraca parafialnych zespołów Caritas i ośrodków pomocy społecznej, funkcjonowanie klubów seniora i uniwersytetów III wieku, działalność poradni rodzinnych).

Powyższe wnioski i postulaty są efektem współpracy teologa pastoralisty z socjologiem religii. Korzystając z diagnozy i prognozy przeprowadzanej w oparciu o wyniki badań socjologicznych ilustrujących pewne tendencje, należy zwrócić uwagę na konieczność posługiwania się danymi wiarygodnymi, zarówno merytorycznie, jak i metodologicznie. Teolog pastoralista pragnący zilustrować odczytywane znaki czasu wynikami badań socjologicznych powinien sięgać do materiału dostarczanego przez odznaczające się profesjonalizmem instytuty badawcze (ISKK SAC, OBOP, CBOS). W wypadku prowadzenia badań własnych, potrzeba właściwie przeprowadzonego procesu badawczego, obejmującego mię-

\footnotetext{
${ }^{52}$ Jej znacznie kulturowe obejmuje zarówno wymiar osobisty (możliwość świętowania stwarza przestrzeń do zachowania nie zdeterminowanej pracą zawodową wolności osobowej), jak i wymiar społeczny (świętowanie pełni funkcję integracyjna).
} 
dzy innymi poprawne skonstruowanie kwestionariusza ankietowego, właściwe dobranie próby badawczej, zgodne z zasadami przeprowadzenie badań, a także ich opracowanie. Uzyskane różną drogą wyniki badań socjologicznych powinny później być właściwie zinterpretowane teologicznie. Potrzeba więc dobrego przygotowania socjologicznego pastoralistów oraz teologicznego socjologów, a także ich wzajemnej i konsekwentnej współpracy. Przestrzenią takiego przygotowania i współpracy mogą być instytuty teologii pastoralnej, działające w ramach wydziałów teologicznych. Aby wypracowane wnioski i postulaty nie pozostały jedynie w sferze akademickiego dyskursu naukowego, konieczne jest otwarcie się i współdziałanie hierarchii kościelnej w realizacji proponowanych wskazań.

Na zakończenie warto podkreślić sugestie Jana Pawła II, który zwracał uwagę na konieczność uwzględnienia w planowaniu pastoralnym pierwszeństwa łaski i modlitwy, gdyż bez tego przedsięwzięcia duszpasterskie kończq się niepowodzeniem (NMI 38), a także przypomnieć jego przestrogę przed czysto statystycznym, ilościowym ujmowaniem wiary ${ }^{53}$. Ostatecznie chodzi o to, aby z pomocą różnych środowisk Ludu Bożego z ufnością wytyczać etapy przyszłej drogi Kościoła (zob. NMI 29). Służyć ma temu współpraca teologów pastoralistów i socjologów, którzy zachowując autonomię oraz poprawność metodologiczną swoich dziedzin naukowych, prowadzić będą wzajemny dialog służący jak najlepszemu urzeczywistnianiu i realizowaniu istoty i misji Kościoła.

${ }^{53}$ J a n P a w eł I I: Przekroczyć próg nadziei. Lublin 1994 s. 89. 